\title{
Soya protein antibodies in man: their occurrence and possible relevance in coeliac disease
}

\author{
MR HAENEY,* BJF GOODWIN, $\dagger$ MEJ BARRATT, $\dagger$ N MIKE, $\ddagger$ P ASQUITH $\ddagger$ \\ From the * Regional Immunology Laboratory and the $\ddagger$ Metabolic Research Unit, East Birmingham \\ Hospital, Birmingham B9 5ST and the †Unilever Research Laboratory, Colworth House, \\ Sharnbrook, Bedford MK44 1LQ
}

SUMMARY Circulating antibodies to soya-derived protein antigens have been measured in patients with duodenitis, Crohn's disease, ulcerative colitis and coeliac disease. Significantly raised antibody titres were found frequently in the coeliac group, particularly those patients showing a suboptimal response to a gluten-free diet, but rarely in subjects with other gastrointestinal diseases. Antisoya activity was not necessarily accompanied by antibodies to other common dietary antigens. We suggest that some coeliacs may have an associated dietary soya sensitivity which could adversely influence their response to gluten withdrawal.

Soya-derived textured vegetable protein is increasingly used as a protein substitute in Western diets. It also replaces more expensive proteins in the diets of young animals, especially calves. Although processing procedures have removed most of the known antinutritional constituents of soya, ${ }^{1}$ the young calf is particularly sensitive to ingestion of certain soya proteins. A systemic, IgG-mediated, immune response to soya has been shown to induce physiological and morphological disturbances of intestinal function which may result in impaired growth performance. ${ }^{2-5}$

There is evidence that soya can cause a malabsorption syndrome in infants. ${ }^{6-9}$ Whether or not it can produce similar effects in normal adults is largely unknown, although feeding trials, in which conventional protein was replaced by soya, showed no significant change in the physiological parameters studied. ${ }^{10}$ Soya is also used in certain diets, for example gluten-free diets (GFD) in the treatment

Accepted for publication 15 July 1981 of coeliac disease. Since coeliac patients have an abnormally permeable intestinal mucosa, ${ }^{11}$ they may absorb a disproportionate amount of any dietary soya fraction possessing immunogenic potential. The resulting immune response to soya could therefore compromise the therapeutic effect of a GFD.

The purpose of this study was to determine firstly, whether antibodies to soya-derived protein antigens occur more frequently in sera from patients with gastrointestinal disease (particularly coeliac disease) compared with healthy controls, and secondly, whether a suboptimal response to gluten withdrawal in coeliac disease could be attributable to an immune reaction to soya.

\section{Patients and methods}

Serum samples (122) were obtained from 38 healthy blood donors and from 84 patients with gastrointestinal disease (Table 1) diagnosed on accepted clinical, endoscopic and histological criteria: these patients included 26 with duodenitis, 34 with either

Table 1 Subjects studied

\begin{tabular}{llcc}
\hline Subject group & Number studied & Sex distribution M:F & Age range (yr) \\
\hline Blood donors & 38 & $11: 27$ & $19-54$ \\
Coeliac disease & 16 & $7: 9$ & 23 \\
$\quad$ GFD-good responder & 7 & $1: 6$ & $18-69$ \\
GFD_poor responder & 26 & $19: 7$ & $28-66$ \\
Duodenitis & 17 & $5: 11$ & $23-60$ \\
Inflammatory bowel disease & 17 & $8: 9$ & $13-66$ \\
$\quad$ Crohn's disease & Ulcerative colitis & 34 & $18-60$ \\
\hline
\end{tabular}


ulcerative colitis (17 cases) or Crohn's disease (17 cases) and 23 with coeliac disease ${ }^{12}$ who had been on a GFD for at least one year. Of the total coeliac group, seven had a suboptimal response to a GFD in that clinical symptoms persisted and repeat jejunal biopsies showed only partial improvement from grade 4 to grade 2 villous damage. We have therefore called this subgroup "GFD-poor responder" and the remaining cases (16) "GFD—good responder."

Circulating antibodies to several soya-derived antigens were measured: these were a heated, ethanol-extracted soya bean meal (HESM), ${ }^{3}$ commercial unheated soya flour (USF) ${ }^{\mathbf{1 3}}$ and cryostat sections of soya bean. Antibodies to HESM were determined by countercurrent immunoelectrophoresis (CCIEP) and by passive haemagglutination. ${ }^{3}$ The haemagglutination results were expressed as the highest dilution showing agglutination of HESM-coated erythrocytes. Antibodies to sections of soya bean were detected by indirect immunofluorescence using a fluorescein-conjugated polyvalent rabbit antiserum to human immunoglobulins (Wellcome). Sera were screened at a dilution of $1 / 8$, positive sera titred and the results expressed as the highest titre showing fluorescence. Antibodies to USF, ovalbumin (Grade V, Sigma), $\beta$-lactoglobulin (BDH), and gluten fraction III $^{14}$ were measured by a micro enzyme-linked immunosorbent assay (ELISA). ${ }^{15}$ Optimal concentrations of ovalbumin (50 $\mu \mathrm{g} / \mathrm{ml}), \beta$-lactoglobulin $(50 \mu \mathrm{g} / \mathrm{ml})$, gluten fraction III $(50 \mu \mathrm{g} / \mathrm{ml})$ and USF $(60 \mu \mathrm{g} / \mathrm{ml})$ in
0.05 $M$ carbonate buffer (pH 9.8) were used to coat Removawells (Dynatech). All test sera were examined at a dilution of $1 / 100$ and antibody detected using IgG fractions of sheep antihuman IgG, IgA and IgM (Nordic Laboratories) labelled with alkaline phosphatase. ${ }^{16}$ Bound enzyme activity was measured by the addition of $p$-nitrophenyl phosphate and the results expressed in ELISA units as the optical density at $400 \mathrm{~nm}$ of the hydrolysed substrate after correction for background activity in wells lacking test sera. ${ }^{13}$ Radio-allergosorbent testing (RAST) ${ }^{17}$ for soya-specific IgE was carried out using an allergosorbent prepared from USF and ${ }^{125} \mathrm{I}$-anti IgE (Pharmacia). Statistical analysis of mean antibody activity in each of the patient groups was performed using the non-paired Student's $t$ test.

\section{Results}

Antibody activity (mean \pm SEM) to soya-derived protein in each of the groups studied is shown in Table 2, and the number of individuals with significant antibody activity is summarised in Table 3 . Using monospecific antisera, the soya antibodies detectable by both the ELISA and immunofluorescent assays were found to be predominantly of IgG class: only the IgG antibody titres for these assays are therefore shown. In particular, no significant soya-specific IgE antibody activity was found. None of the sera from normal healthy adults had significant activities of IgG antibody to soya by

Table 2 Soya antibody activity (group mean $\pm S E M$ ) in patients with gastrointestinal disease

\begin{tabular}{|c|c|c|c|c|c|c|c|c|}
\hline \multirow{2}{*}{$\begin{array}{l}\text { Experimental } \\
\text { method }\end{array}$} & \multicolumn{3}{|c|}{ Coeliac disease } & \multirow{2}{*}{$\begin{array}{l}\text { Duodenitis } \\
n=26\end{array}$} & \multicolumn{3}{|c|}{ Inflammatory bowel disease } & \multirow{2}{*}{$\begin{array}{l}\text { Blood donors } \\
n=38\end{array}$} \\
\hline & $\begin{array}{l}\text { Total } \\
n=23\end{array}$ & $\begin{array}{l}G F D-g o o d \\
\text { responder } \\
n=16\end{array}$ & $\begin{array}{l}G F D \text {-poor } \\
\text { responder } \\
n=7\end{array}$ & & $\begin{array}{l}\text { Total } \\
n=34\end{array}$ & $\begin{array}{l}\text { Crohn's } \\
\text { disease } \\
n=17\end{array}$ & $\begin{array}{l}\text { Ulcerative } \\
\text { colitis } \\
n=17\end{array}$ & \\
\hline $\begin{array}{l}\text { Haemagglutination } \\
\text { (log, titre) } \\
\text { IgG-ELISA (units) } \\
\text { Immunofluorescence }\end{array}$ & $\begin{array}{l}3.52 \pm 0.43 \\
0.49 \pm 0.09\end{array}$ & $\begin{array}{l}3.50 \pm 0.53 \\
0.35 \pm 0.05\end{array}$ & $\begin{array}{l}3.57 \pm 0.28 \\
0.81 \pm 0.26\end{array}$ & $\begin{array}{l}2.15 \pm 0.28 \\
0.15 \pm 0.03\end{array}$ & $\begin{array}{l}0.26 \pm 0.09 \\
0.24 \pm 0.02\end{array}$ & $\begin{array}{l}0.24 \pm 0.11 \\
0.30 \pm 0.04\end{array}$ & $\begin{array}{l}0.18 \pm 0.10 \\
0.18 \pm 0.01\end{array}$ & $\begin{array}{l}0.89 \pm 0.22^{*} \\
0.23 \pm 0.02^{*}\end{array}$ \\
\hline$\left(\log _{2}\right.$ titre) & $3 \cdot 26 \pm 0.38$ & $2.63 \pm 0.43$ & $4 \cdot 71 \pm 0.47$ & $1 \cdot 67 \pm 0 \cdot 14$ & $1 \cdot 79 \pm 0.17$ & $1.88 \pm 0.14$ & $1 \cdot 71 \pm 0 \cdot 22$ & $1 \cdot 19 \pm 0.08$ \\
\hline
\end{tabular}

*n $=27$.

Table 3 Number of individuals showing significant anti-soya antibody activity

\begin{tabular}{|c|c|c|c|c|c|c|}
\hline \multirow[t]{2}{*}{ Method of antibody detection } & \multicolumn{2}{|c|}{ Coeliac disease $n=23$} & \multirow{2}{*}{$\begin{array}{l}\text { Duodenitis } \\
n=26\end{array}$} & \multicolumn{2}{|c|}{ Inflammatory bowel disease $n=34$} & \multirow{2}{*}{$\begin{array}{l}\text { Blood donors } \\
n=38\end{array}$} \\
\hline & & $\begin{array}{l}G F D \text { _poor responder } \\
n=7\end{array}$ & & $\begin{array}{l}\text { Crohn's disease } \\
n=17\end{array}$ & $\begin{array}{l}\text { Ulcerative colitis } \\
n=17\end{array}$ & \\
\hline $\begin{array}{l}\text { Countercurrent } \\
\text { immunoelectrophoresis } \\
\text { Haemagglutination * }\end{array}$ & 1 & 2 & $\mathbf{0}$ & $\mathbf{0}$ & 0 & 0 \\
\hline $\begin{array}{l}\left(\log _{2} \text { titre }>5\right) \\
\text { IgG-ELISA }(>0.47 \text { units) } \\
\text { Immunofluorescence* }\end{array}$ & $\begin{array}{l}5 \\
4\end{array}$ & $\begin{array}{l}2 \\
4\end{array}$ & $\begin{array}{l}1 \\
0\end{array}$ & $\begin{array}{l}0 \\
2\end{array}$ & $\begin{array}{l}\mathbf{0} \\
\mathbf{0}\end{array}$ & $\begin{array}{l}\mathbf{0} \\
\mathbf{0}\end{array}$ \\
\hline
\end{tabular}

*Significant values of antibody activity for each assay shown in brackets. 
any of the techniques used.

Mean $\log _{2}$ haemagglutinating antibody titres to soya were significantly higher in patients with coeliac disease than in the control population $(p<0.05)$ and patients with inflammatory bowel disease $(p<0.05)$. Mean values in the "GFD—good responder" and "GFD_poor responder" coeliac subgroups were not significantly different.

Soya-specific IgG antibody detected by ELISA is shown in the Figure. The mean titre in the "GFDpoor responder" coeliac subgroup was significantly higher than in the "GFD_good responder" subgroup ( $<<0.05)$, healthy controls $(\mathrm{p}<0.05)$ patients with duodenitis $(\mathrm{p}<0.05)$ or inflammatory bowel disease $(p<0.05)$.

Immunofluorescent studies on soya bean (Tables 2 and 3) showed that whereas very few of the healthy or patient control sera demonstrated significant fluorescence beyond the initial screening dilution of $1 / 8$, three of the "GFD-good responder" coeliacs and six of the seven "GFD-poor responder" coeliacs had raised titres.

Finally, there was no correlation between titres of IgG-ELISA antibodies to different dietary antigens in either the seven "GFD-poor responder" coeliacs (Table 4) or the "GFD—good responder" subgroup (results not shown).

\section{Discussion}

Normal healthy persons had only low activities of antibody to soya in amounts that probably reflect no more than harmless exposure. On the other hand, significant anti-soya antibodies have been found more commonly in patients with coeliac disease, particularly in the "GFD-poor responder" subgroup, than in patients with other gastrointestinal diseases. This humoral immune response to soya could be of pathogenetic significance or alternatively it may simply reflect inadequate dietary gluten restriction resulting in continuing villous damage and increased mucosal permeability to many dietary antigens: however, several lines of evidence suggest that this alternative hypothesis is less likely. Firstly, the "GFD—poor responder" coeliacs in this study were reliable patients known to be adhering to their GFD and confirmed by random domestic visits from a trained dietician. Secondly, although inflammatory bowel disease is commonly associated with antibodies to dietary antigens ${ }^{11} 1819$ the mean soya antibody level in this group was similar to healthy controls (Table 2) although two

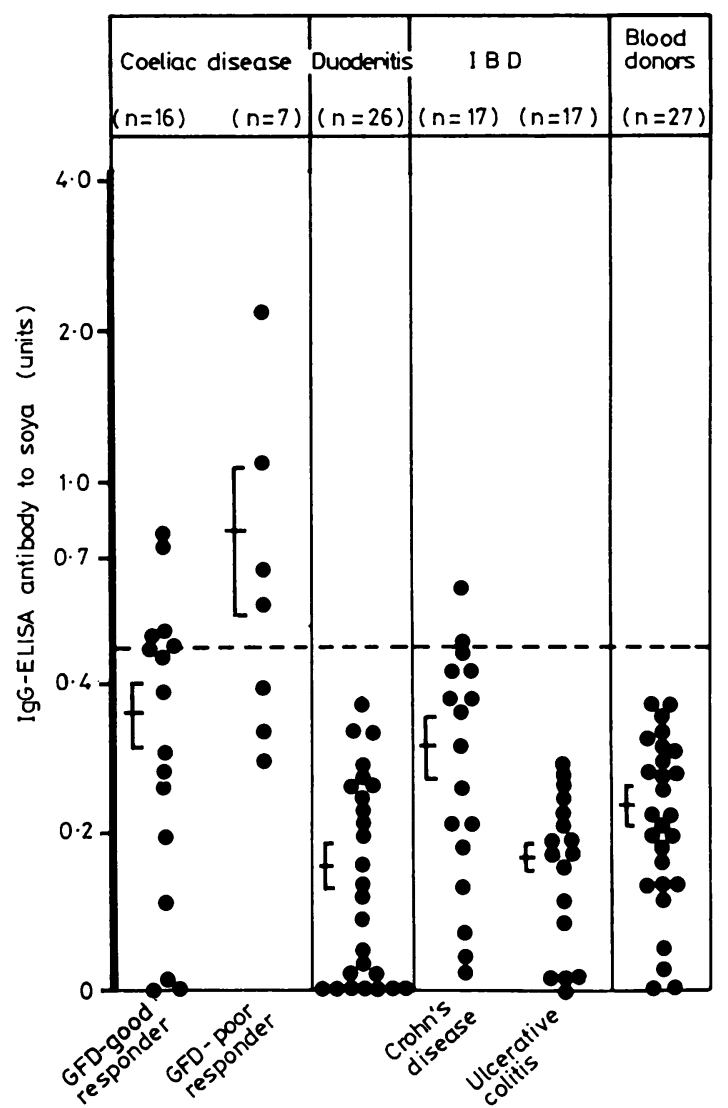

Soya-specific IgG antibody detected by ELISA. Units of antibody activity are shown on a log scale. The dotted line indicates the upper limit of the normal range $($ mean $+3 S D)$ and the vertical barred lines depict group means \pm 1 SEM.

Table 4 IgG-ELISA antibodies* to dietary antigen in "GFD_poor responder" coeliacs

\begin{tabular}{|c|c|c|c|c|}
\hline Patient & Soya $(N R=0-0.47 U)$ & Gluten $(N R=0-0.31 \mathrm{U})$ & $\beta$-lactoglobulin $(N R=0-0.46 \mathrm{U})$ & Ovalbumin $(N R=0-0.93 \mathrm{U})$ \\
\hline $\begin{array}{l}1 \\
2 \\
3 \\
4 \\
5 \\
6 \\
7\end{array}$ & $\begin{array}{l}2 \cdot 16^{*} \\
0 \cdot 32 \\
0 \cdot 67^{*} \\
0 \cdot 58^{*} \\
0 \cdot 38 \\
0 \cdot 28 \\
1 \cdot 26^{*}\end{array}$ & $\begin{array}{l}0.11 \\
0.28 \\
0.56^{*} \\
1.15^{*} \\
0.87^{*} \\
0.26 \\
0.22\end{array}$ & $\begin{array}{l}0.18 \\
1.08 * \\
0.12 \\
0.36 \\
0.32 \\
0.45 \\
0.96^{*}\end{array}$ & $\begin{array}{l}0.08 \\
0.52 \\
0.13 \\
0.81 \\
0.46 \\
1.05^{*} \\
1.84^{*}\end{array}$ \\
\hline
\end{tabular}

*Significantly raised activities. 
individuals had raised IgG antibodies to soya (Figure). Thirdly, if soya antibody formation resulted from increased mucosal permeability, then antisoya activity might be expected to show some correlation with antibody activities to other common dietary antigens. This is not the case: some coeliacs with soya antibodies showed no antibody activity to the other antigens, while conversely, antibodies to gluten, ovalbumin, and $\beta$-lactoglobulin were found in other coeliacs lacking soya antibodies (Table 4).

If this immune response is not secondary to abnormal mucosal permeability, then soya may be implicated in the pathogenesis of the "GFD-poor responder" state. This could develop because certain coeliacs have an associated sensitivity to dietary soya in addition to their gluten intolerance.

We thank Dr WE Parish, Dr P Porter and Dr RA Thompson for helpful discussions and Mrs R Barber and Miss $L$ Underwood for their expert technical assistance. Dr N Mike is in receipt of a Sheldon Research Fellowship from the West Midlands Regional Health Authority.

\section{References}

${ }^{1}$ Rackis JJ. Biological and physiological factors in soybeans. J Am Oil Chem Soc 1974;51:161A-74A.

${ }^{2}$ Smith RH, Sissons JW. The effect of different feeds, including those containing soya-bean products, on the passage of digesta from the abomasum of the preruminant calf. Br J Nutr 1975;33:329-49.

${ }^{3}$ Barratt MEJ, Strachan PJ, Porter P. Antibody mechanisms implicated in digestive disturbances following ingestion of soya protein in calves and piglets. Clin Exp Immunol 1978;31:305-12.

${ }^{4}$ Barratt MEJ, Porter P. Immunoglobulin classes implicated in intestinal disturbances of calves associated with soya protein antigens. J Immunol 1979;123:676-80.

${ }^{5}$ Kilshaw PJ, Sissons JW. Gastrointestinal allergy to soybean protein in preruminant calves. Antibody production and digestive disturbances in calves'fed heated soyabean flour. Res Vet Sci 1979;27:361-5.

- Ament ME, Rubin CE. Soy protein-another cause of the flat intestinal lesion. Gastroenterology 1972;62: 227-34.

${ }^{7}$ Kuitunen P, Visakorpi JK, Savilahti E, Pelkonen P. Malabsorption syndrome with cow's milk intolerance. Clinical findings and course in 54 cases. Arch Dis Child 1975;50:351-6.

${ }^{8}$ Whitington PJ, Gibson R. Soy protein intolerance: four patients with concomitant cow's milk intolerance. Pediatrics 1977;59:730-2.

- Powell GK. Milk-and soy-induced enterocolitis of infancy. J Pediatr 1978;93:553-60.

10 Van Stratum P. Physiological effects of a high soybean diet in man. Cereal Foods World 1978;23:235-9.

${ }^{11}$ Taylor KB, Truelove SC, Wright R. Serologic reactions to gluten and cow's milk proteins in gastrointestinal disease. Gastroenterology 1964;46:99-108.

12 Cooke WT, Asquith P. Coeliac disease. Clin Gastroenterol 1974;3:3-10.

${ }^{13}$ Goodwin BJF. IgE antibodies to ingested soya protein in a normal adult population. Clin Allergy 1981; (in press).

${ }^{14}$ Frazer AC, Fletcher EF, Ross CAC, Shaw B, Sammons HG, Schneider R. Gluten-induced enteropathy. The effect of partially digested gluten. Lancet 1959;ii:252-5.

${ }^{15}$ Voller A, Bidwell D, Bartlett A. Microplate enzyme immunoassays of virus infections. In: Rose NR, Friedman $\mathrm{H}$, eds. Manual of clinical immunology. American Society of Microbiology, 1976:506.

${ }^{16}$ Engvall E, Perlmann P. Enzyme-linked immunosorbent assay, ELISA. III Quantitation of specific antibodies by enzyme-labelled anti-immunoglobulin in antigen-coated tubes. J Immunol 1972;109:129-35.

17 Wide L, Bennich H, Johansson SGO. Diagnosis of allergy by an in vitro test for allergen antibodies. Lancet 1967; ii:1105-7.

18 Taylor KB, Truelove SC. Circulating antibodies to milk proteins in ulcerative colitis. Br Med J 1961 ;ii:924-9.

19 Falchuk KR, Isselbacher KJ. Circulating antibodies to bovine albumin in ulcerative colitis and Crohn's disease. Gastroenterology 1976;70:5-8.

Requests for reprints to: Dr MR Haeney, Department of Immunology, Clinical Sciences Building, Hope Hospital, Salford M6 8HD, England. 